\title{
ANTIBACTERIAL ACTIVITY IN EARTHWORM COELOMIC FLUID LAMPITO MAURITII
}

\author{
Deepthi, M P. and P. Kathireswari* \\ Department of Zoology, Konganadu Arts and Science College, Coimbatore. \\ *E.mail: kathireswari@gmail.com
}

\begin{abstract}
Earthworms are the first annulated coelomate organism with haemoglobin in the plasma as carrier of oxygen and carbon dioxide. They have the antimicrobial activity against the disease causing micro organisms. In the present study antibacterial activity of earthworm coelomic fluid Lampito mauritii were confined against disease causing micro organisms through the inhibition zone formation by well diffusion method as well as disc diffusion method.
\end{abstract}

Keywords: Earthworm, antibacterial, coelomic fluid, inhibition zone.

\section{INTRODUCTION}

Earthworms are natural invertebrates of agro ecosystem belonging to the Phylum Annelida, and dominant in the temperate and tropical soils. They are the first group of multicellular eucoelomate invertebrates to have succeeded to inhabit terrestrial environment (Kale and Karmegam, 2010). Being hermaphrodites, both male and female reproductive organs are present in every single earthworm but self-fertilization does not generally occur. Earthworms, as ecosystem engineers, play an important role in many soil ecosystems and are one of the numerous ranges of burrowing organisms, which improve soils (Lavelle, 1997). Due to their relatively large size and characteristic feeding behaviour, certain species have significant impacts on soil structure, soil fertility, plant growth and crop yields.

Earthworm provides optimum conditions for plant growth by reducing both acidity and alkalinity of soil. Plant growth stimulants such as auxins are produced in the earthworm castings. These hormones stimulate roots to grow faster and deeper. A more important beneficial effect of soil is the mixing and changing of soil texture caused by burrowing and improves water filtration rates and absorption rates of soil. The tunneling activity improves soil aeration and permeability.

The swallowed materials are digested and only $10 \%$ is absorbed. The remaining $90 \%$ us passed out as earthworm casts. In the healthy soil 40 tonnes of soils per acre pass through the bodies of earthworm daily. One earthworm digests 36 tonnes of soil in one year (US soil conservation office)
Now a day the research on earthworm not only focused on agricultural aspects in the therapeutic areas. In Chinese medicine earthworm is considered as complete medicine and used for various therapeutic purposes such as blood purification, blood disorders, against jaundice, wound healing and as antimicrobial, anti inflammatory and anti oxidant agent. The most important characteristics of the immune system of animals in the phylum Annelida are that they have developed a coelom. This body cavity contains coelomic fluid, in which coelomocytes, the worm's leukocytes, are suspended. Coelomocytes are not contained within the circulatory system but are sensitive to perturbations such as infections and are active in defense reaction ranging from phagocytosis to the more complex mechanism of tissue graft rejection. Infection by a pathogen represents one of the major threats to any living organisms. These pathogens are firstly bacteria living in water or soil that are ingested during feeding or introduced into the body following injury. During the course of evolution, earthworms have developed defense strategies against these living pathogens. Earthworms lack true antibodies and hence an adaptive immune response and instead have efficient innate immunity system to defend themselves against invading foreign materials. In living organisms, peptides are an important defense component, many peptides were found in various living organisms. Therefore it can be supposed that earthworm living in the pathogen- abundant environment must have peptides against bacteria. In earthworms innate immunity is maintained by cellular components, different coelomocytes (leukocytes), housed in coelomic cavity whose fluid 
also contains many immunological (antimicrobial) active molecules. The component of coelomic fluid of earthworm defenses them in identifying foreign substance and develops potency to fight against them. Studies done by many workers have strongly pointed out that coelomic fluid of earthworms like Eisenia foetida, Eudrilus euginae, Polypheretima elongata, Perionyx excavatus, Lampito mauritii, Dendrobaena veneta, Lumbricus terresteris, $L$. rubellus and Perionyx sansibaricus have medicinal and antibacterial properties (Çotuk and Dales, 1984; Dales and Kalaç 1992; Milochau et al., 1997; Balamurgan et al., 2007). The lysozyme performs lytic activity which can be used to manage the wastes of various organic substances. Moreover, earthworms have been used to treat upper respiratory tract infections, typhoid, and diarrheal pathogenic bacteria as a natural drug in Indonesia more than 50 years. The present study of earthworm antibacterial activity is conducted in the peregrine species Lampito mauritii.

\section{MATERIALS AND METHODS}

\subsection{Colection and culture of bacteria}

Four different types of bacteria namely Escherichia coli (Gram negative), Klebsiella pneumoniae (Gram-negative), Enterococcus faecalis (Gram-positive) and Staphylococcus aureus were purchased from Bioline lab Coimbatore, Tamil Nadu (India) and they were transferred separately on fresh nutrient agar medium at $35^{\circ} \mathrm{C}$ to $37^{\circ} \mathrm{C}$ for 24 hours to obtain active culture. Each bacterium was transferred separately to fresh nutrient broth from this active culture was incubated at $35^{\circ} \mathrm{C}$ to $37^{\circ} \mathrm{C}$ for 24 hour to get active culture suspension.

Table 1. Composition of nutrient agar medium.

\begin{tabular}{cc}
\hline INGREDIENTS & Gms / lit \\
\hline Peptone & 0.5 \\
Nacl & 0.5 \\
Beef extract & 0.3 \\
Yeast extract & 0.3 \\
Agar powder & 2.5 \\
Distilled water & $100 \mathrm{ml}$ \\
\hline
\end{tabular}

\subsection{Extraction of earthworm coelomic fluid}

Fifteen adult earthworms Lampito mauritii (average length $10 \mathrm{~cm}$ ) collected from the garden of Konganadu arts and Science College, Coimbatore, Tamil Nadu (India) and thoroughly washed with tap water and then with sterile distilled water and dried with sterile blotting paper. The coelomic fluid can be directly collected from the body cavity of earthworms without causing any harm to them. In this method of collecting the fluid, three to four earthworms are taken in an approximately $10 \mathrm{~cm}$ diameter petriplate and holding the plates in a slanting position and keep earthworms pointing downwards. Cold shock is given to earthworm by gently moving a small beaker containing a few ice cubes. The coelomic fluid released due to cold shock drips and gets collected at the lower side of the Petri plate. This fluid can be pipette out using a sterilized pipette with fine nozzle. This is the pure coelomic fluid that can be used for different biological investigations (Radha and Kale, 2006).

\subsection{Preparation of Paper Disc}

Sterile what man number1 filter papers were used to prepare the discs for absorbing the coelomic fluid of earthworms and standard ampicilline is used for experimental control. This was done, first by punching out several small discs (5 $\mathrm{mm}$ in diameter) and then impregnated with coelomic fluid until complete absorption. Several nutrient agar medium were prepared and plate was inoculated with $0.1 \mathrm{ml}$ for 24 hours and spreader over petridish with glass spreader. Then each petridish was inoculated with 5 anti biotic disc, among these one is kept as control and other each one with earthworm pure coelomic fluid, earthworm coelomic fluid and alcohol, coelomic fluid and distilled water, and earthworm paste (it is prepared by cutting the tail region of earthworm and grind them in a mortar and pistle) for the disc diffusion method and these four samples were poured in to the wells of petriplate for well diffusion method. After that each plate is allowed to incubate at $35^{\circ} \mathrm{C}-$ $37^{\circ} \mathrm{C}$ for 24 hour. After 24 hour inhibition zone of each plate was measured with a scale.

\section{RESULTS AND DISCUSSION}

To the antimicrobial activity of coelomic fluid the inhibition zone formation around the coelomic fluid was noted and measured the diameter of that inhibition zone range. The antimicrobial activity of earthworm Lampito mauritii were tested against disease causing micro organisms namely Escherichia coli, Klebssellia pneumonia, staphylococcus aureus, streptococcus faecalis through the inhibition formation ranging at 8-15 by well diffusion method and $6-15$ by disc diffusion method. The result of well diffusion method showed that sample 'B' (coelomic fluid and alcohol) have the high antibacterial activity against the bacteria Enterococcus faecalis and less activity was found in E.coli as wella as Klebseilla pneumoniae. 
Table 2. Measurement of zone formation by well diffusion method.

\begin{tabular}{lcccc}
\hline Sample/Name of bacteria & E.coli & $\begin{array}{c}\text { Klebseilla } \\
\text { pneumonia }\end{array}$ & $\begin{array}{c}\text { Enterococcus } \\
\text { faecalis }\end{array}$ & $\begin{array}{c}\text { Staphylococcus } \\
\text { aureus }\end{array}$ \\
\hline A-Control & $8.0 \mathrm{~mm}$ & $8.0 \mathrm{~mm}$ & $9.0 \mathrm{~mm}$ & $8.0 \mathrm{~mm}$ \\
B-Coelomic fluid + alcohol & $9.0 \mathrm{~mm}$ & $9.0 \mathrm{~mm}$ & $15 \mathrm{~mm}$ & $15 \mathrm{~mm}$ \\
C- Pure Coelomic Fluid & $15 \mathrm{~mm}$ & $10 \mathrm{~mm}$ & $10 \mathrm{~mm}$ & $10 \mathrm{~mm}$ \\
D-Earthworm paste & $10 \mathrm{~mm}$ & $12 \mathrm{~mm}$ & $15 \mathrm{~mm}$ & $15 \mathrm{~mm}$ \\
E-Coelomic fluid + distilled & $12 \mathrm{~mm}$ & $8.0 \mathrm{~mm}$ & $8.0 \mathrm{~mm}$ & $9.0 \mathrm{~mm}$ \\
water & 12 &
\end{tabular}

Earthworm pure coelomic fluid showed the maximum zone formation against the bacteria E.coli and minimum zone formation in other three bacteria. Earthworm paste showed the maximum zone formation in two bacteria namely Enterococcus fecalis and Staphylococcus aureus. The sample E (coelomic fluid and distilled water) forms the minimum zone formation when compared to other three samples. The control forms the less inhibition zone against all bacteria.

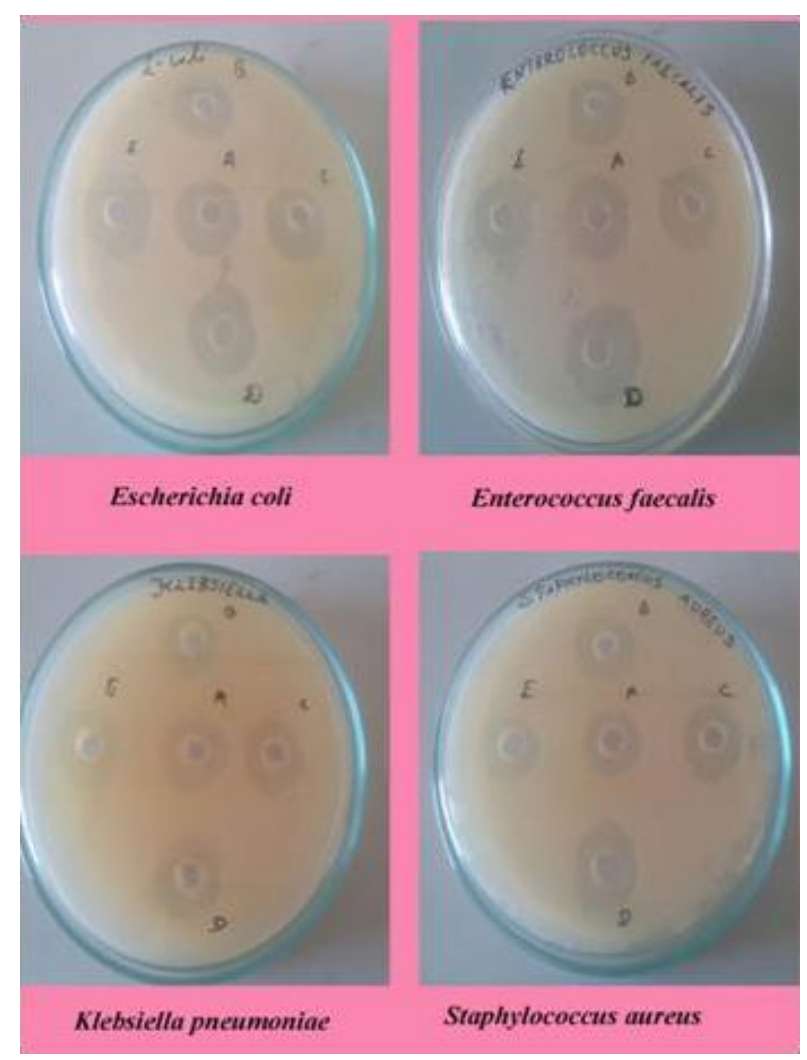

Fig. 1. Measurement of zone formation by well diffusion method

The result of disc diffusion method forms the inhibition zones ranging from $6.0 \mathrm{~mm}$ to $15 \mathrm{~mm}$. The control forms maximum inhibition zone against the bacteria Enterococcus fecalis $(10 \mathrm{~mm})$ and minimum in Klebseilla pneumonia $(6.0 \mathrm{~mm})$. The sample B forms the maximum zone in Staphylococcus aureus $(9.0 \mathrm{~mm})$ and minimum zone in E.coli $(6.0$ $\mathrm{mm})$. The sample $\mathrm{C}$ showed the maximum zone formation in E.coli $(15 \mathrm{~mm})$ and minimum zone in two bacteria namely Klebseilla pneumonia and Staphylococcus aureus. Sample D forms the maximum zones in Enterococcus fecalis (15 $\mathrm{mm}$ ) and minimum In Klebseilla pneumoniae $(9.0 \mathrm{~mm})$ and sample have the maximum zone formation in Staphylococcus aureus $(15 \mathrm{~mm})$ and minimum in E.coli $(9 \mathrm{~mm})$.

Earthworm is a first terrestrial invaded organism and if serving on soil with millions of microorganisms. The antimicrobial activity in the coelomic fluid of earthworm may be because of innate immune mechanism and detect microorganism by recognizing conserved molecular pattern. The Asian countries like China and Korea are aimed at using earthworms in pharmaceutical applications. They have isolated enzymes and other active principles that can serve as antibiotics and anti-tumor agents. They have made detail studies on fibrinolytic enzymes of earthworms have also found their way in the preparation of cosmetics as a factor to delay ageing.

Lampito mauritii belongs to the family Megascolecidae and most of the sopecies of this family have melanin pigment on their body. In the above study we got good antimicrobial activity in Lampito mauritii against four disease causing bacteria namely E.coli, Klebsiella pnumoniae, Enterocoocus fecalis, and staphylococcus aureus. Escherichia coli (also known as E. coli) is a Gramnegative, facultative anaerobic, rod-shaped bacterium of the genus Escherichia that is commonly found in the lower intestine of warm-blooded organisms (endotherms) (Singleton, 1999). 
Table 3. Measurement of zone formation by disc diffusion method.

\begin{tabular}{lcccc}
\hline Sample/Name of bacteria & E.coli & $\begin{array}{c}\text { Klebseilla } \\
\text { pneumonia }\end{array}$ & $\begin{array}{c}\text { Enterococcus } \\
\text { faecalis }\end{array}$ & $\begin{array}{c}\text { Staphylococcus } \\
\text { aureus }\end{array}$ \\
\hline A-Control & $8.0 \mathrm{~mm}$ & $6.0 \mathrm{~mm}$ & $10 \mathrm{~mm}$ & $7.0 \mathrm{~mm}$ \\
B-Coelomic fluid + alcohol & $6.0 \mathrm{~mm}$ & $7.0 \mathrm{~mm}$ & $8.0 \mathrm{~mm}$ & $9.0 \mathrm{~mm}$ \\
C- Pure Coelomic Fluid & $15 \mathrm{~mm}$ & $0.8 \mathrm{~mm}$ & $0.9 \mathrm{~mm}$ & $0.8 \mathrm{~mm}$ \\
D-Earthworm paste & $10 \mathrm{~mm}$ & $9.0 \mathrm{~mm}$ & $15 \mathrm{~mm}$ & $10 \mathrm{~mm}$ \\
E-Coelomic fluid + distilled & $9.0 \mathrm{~mm}$ & $10 \mathrm{~mm}$ & $10 \mathrm{~mm}$ & $15 \mathrm{~mm}$ \\
water & & & & \\
\hline
\end{tabular}

Most E. coli strains are harmless, but some serotypes can cause serious food poisoning in their hosts, and are occasionally responsible for product recalls due to food contamination. The harmless strains are part of the normal flora of the gut, and can benefit their hosts by producing vitamin $\mathrm{K}_{2}$, and preventing colonization of the intestine with pathogenic bacteria. E. coli is expelled into the environment within fecal matter. The bacterium grows massively in fresh fecal matter under aerobic conditions for 3 days, but its numbers decline slowly afterwards. Klebsiella pneumoniae is a Gramnegative, nonmotile, encapsulated, lactosefermenting, facultative anaerobic, rod-shaped bacterium. Although found in the normal flora of the mouth, skin, and intestines, (Ryan and Ray, 2004). it can cause destructive changes to human and animal lungs if aspirated (inhaled), specifically to the alveoli (in the lungs) resulting in bloody sputum. In the clinical setting, it is the most significant member of the Klebsiella genus of Entero bacteriaceae. $K$. oxytoca and $K$. rhinoscleromatis have also been demonstrated in human clinical specimens. In recent years, Klebsiella species have become important pathogens in nosocomial infections. As a general rule, Klebsiella infections are seen mostly in people with a weakened immune system. Most often, illness affects middle-aged and older men with debilitating diseases. This patient population is believed to have impaired respiratory host defenses, including persons with diabetes, alcoholism, malignancy, liver disease, chronic obstructive pulmonary diseases, gluco-corticoid therapy, renal failure, and certain occupational exposures (such as papermill workers). Many of these infections are obtained when a person is in the hospital for some other reason (a nosocomial infection). Feces are the most significant source of patient infection, followed by contact with contaminated instruments.

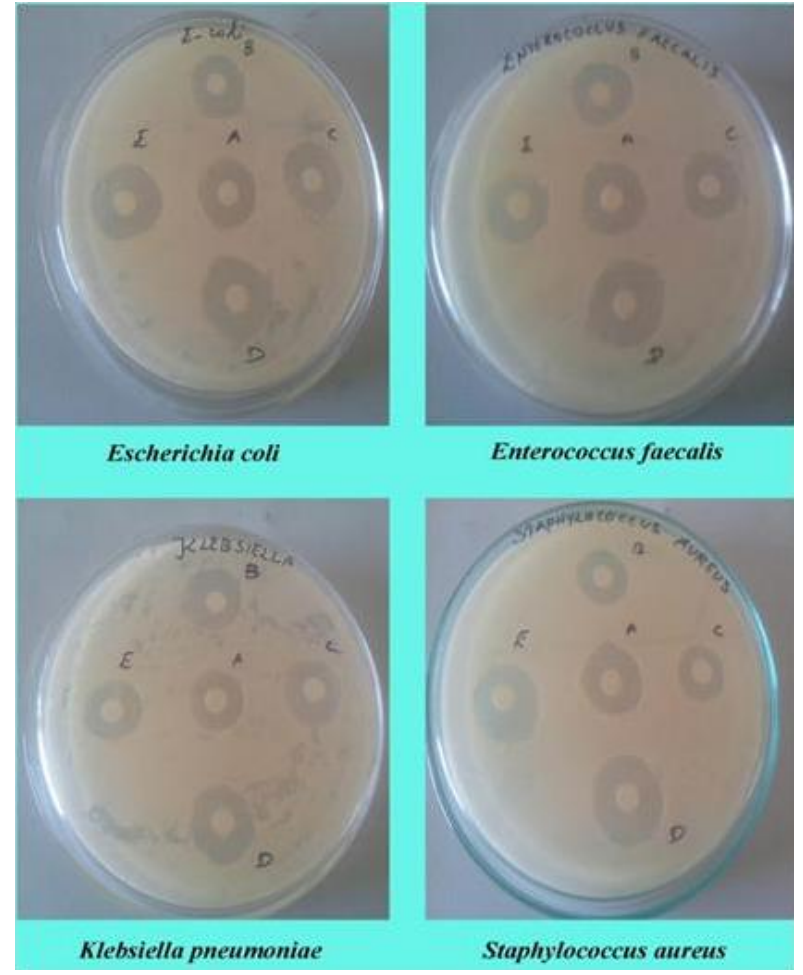

Fig. 2. Measurement of zone formation by disc diffusion method.

Enterococcus faecalis formerly classified as part of the group D Streptococcus system - is a Grampositive bacterium inhabiting the gastrointestinal tracts of humans and other mammals (Ryan and Ray, 2004). Like other species in the genus Enterococcus, E. faecalis can cause life-threatening infections in humans, especially in the nosocomial (hospital) environment, where the naturally high levels of antibiotic resistance found in E. faecalis contribute to its pathogenicity. E. faecalis can cause endocarditis and septicemia, urinary tract infections, meningitis, and other infections in humans (Murray, 1990; Hidron et al., 2008). Staphylococcus aureus is a grampositive coccal bacterium that is a member of the Firmicutes, and is frequently found in the nose, 
respiratory tract, and on the skin. It is often positive for catalase and nitrate reduction. Although S. aureus is not always pathogenic, it is a common cause of skin infections such as abscesses, respiratory infections such as sinusitis, and food poisoning. Pathogenic strains often promote infections by producing potent protein toxins, and expressing cellsurface proteins that bind and inactivate antibodies. In this study we have selected the four samples of earthworm Lampito mauritii, that include pure coelomic fluid, coelomic fluid and alcohol (methanol), coelomic fluid and distilled water and earthworm paste. These four sample forms the inhibition zones against above mentioned bacteria.

\section{REFERENCES}

Balamurugan, M., K. Parthasarathi, E. Cooper and L.S. Ranganathan, (2007). Earthworm paste (Lampito mauritii, Kinberg) alters inflammatory, oxidative, haematological and serum biochemical indices of inflamed rat. Europ. Rev. Med. Pharmacol. Sci. 11:77-90

Çotuk, A., and P.R. Dales, (1984). The effect of the coelomic fluid of the earthworm Eisenia foetida sav. on certain bacteria and the role of the coelomocytes in internal defence. Comp. Biochem. Physiol. 78A(2): 271-275.

Dales, R.P. and Y. Kalaç, (1992). Phagocytic defence by the earthworm Eisenia foetida against certain pathogenic bacteria. Comp. Biochem. Physiol. 101A: 487-490.

Hidron, A.I., J.R. Edwards and J. Patel, ( 2008). NHSN annual update: antimicrobial-resistant pathogens associated with healthcare- associated infections: annual summary of data reported to the National Healthcare Safety Network at the Centers for Disease Control and Prevention, 2006-2007. Infect Control Hosp. Epidemiol. 29(11): 996-1011. doi:10.1086/591861. PMID 18947320.

Kale, R.D. and N. Karmegam, (2010). The Role of Earthworms in Tropics with Emphasis on Indian Ecosystems. Appl. Environ. Soil Sci. 1-16.

Lavelle, P., (1997). Faunal activities and soil processes: Adaptive strategies that determine ecosystem function. Adv. Ecol. Res. 24: 93-132.

Milochau, A., M. Lassegues and P. Valembois, (1997). Purification, characterization and activities of two hemolytic and antibacterial proteins from coelomic fluid of the annelid Eisenia fetida Andrei. Biochimicaet Biophysica Acta.1337: 123-132.

Murray, B.E., (1990). The life and times of the Enterococcus. Clin. Microbiol. Rev. 3(1): 46-65. PMC 358140. PMID 2404568.

Radha, D. Kale, (2006). Vermicompost-Crown of Organic farming. Inhouse Publication. Jayanthi Printery Bangalore, Karnataka, India.

Ryan, K.J. and C.G. Ray, (2004). Sherris Medical Microbiology (4th ed.). McGraw Hill. ISBN 08385-8529-9.

Singleton, P. (1999). Bacteria in Biology, Biotechnology and Medicine (5th ed.). Wiley. pp. 444-454. ISBN 0-471-98880-4. 